\title{
Salt Dependency of the Bacterial Flora of Marine Fish
}

\author{
By U. SIMIDU AND KAZUYO HASUO \\ The Institute of Food Microbiology, Chiba University, \\ Narashino-shi, Chiba-ken, Japan
}

(Accepted for publication 23 January 1968 )

S UMM A R Y

The bacterial flora on the skin of plaice (Kareius bicoloratus) caught in coastal regions of Japan was composed of bacterial groups heterogenous to the concentration of salt in their growth behaviour. Each bacterial group had a different minimum and/or maximum salt concentration for growth, and different groups were selected by media with different salt concentration. In the media based on two complex salt solutions, including an artificial sea water, the maximum bacterial counts were obtained at concentrations corresponding to about $25 \%$ dilution of sea water. During the storage of fish at $24^{\circ}$ and $2^{\circ}$, bacteria which required higher salt concentrations for growth increased faster than that of non-halophilic bacteria. The microflora of the digestive tract of the fish was composed almost exclusively of halophilic vibrios.

\section{INTRODUCTION}

A previous survey on the sea water from coastal areas of Japan (Simidu \& Aiso, 1962) showed that an appreciable number of sea water bacteria required at least $0.2 \%$ sodium chloride for their growth. Most of these bacteria retained their halophilic nature after serial subcultures. These results suggested that a large proportion of the bacteria of fish from the same environment might also be halophilic in nature. If this were the case, the halophilic nature of fish bacteria might be of some significance in the spoilage of fish. Although many workers presuppose the halophilic nature of fish bacteria, there is little information on the actual distribution of halophilic bacteria in the microflora of marine fish; and their possible role before and after the death of the fish is still obscure. In the present report, the growth behaviour of the bacterial population as well as of individual isolates from marine fish were studied at different salt concentrations.

\section{METHODS}

The experiments were done during the months October to May.

Plaice, 'Ishigarei' (Kareius bicoloratus), weighing I20-680 g., were bought at Funabashi Fish Market, Chiba Prefecture. The fish had been sent alive to the market without refrigeration. Although 4 to $5 \mathrm{hr}$ had elapsed from the time of catching, the fish were in most cases still alive at the beginning of the experiment. Skin of the middle dorsal part of the fish $\left(6.0\right.$ or $9.0 \mathrm{~cm} .{ }^{2}$ in area) with or without underlying muscle, was excised aseptically from the fish. The skin sample was homogenized with 50-100 ml. of a salt solution: $0.85 \% \mathrm{NaCl}$ in the experiments to see the effect of $\mathrm{NaCl}$ solution and an artificial sea water, and a mixed solution consisting of $0.8 \% \mathrm{NaCl}$ 
and $1.0 \% \mathrm{KCl}$ in the experiments with solution $\mathrm{C}$. From serial dilutions, $0.5 \mathrm{ml}$. of the homogenate was placed in triplicate on plates by using a mechanical pipette (Yanagita \& Maruyama, 1953) to ensure a fast and accurate procedure. Agar medium $\left(20 \mathrm{ml}\right.$.) was poured into the plate; plates were incubated at 23 to $25^{\circ}$ for 4 to 7 days.

Three different mixtures of medium and salt solution were used. In the first series of experiments, I $.0 \%$ Polypepton (Daigo Eiyo Kagaku Co., Osaka), 0.5\% meat extract (Kyokuto Seiyaku Kogyo Co., Tokyo) and $\mathrm{I} \cdot 2 \%$ agar were dissolved in solutions of sodium chloride of various concentrations. In the second series, the same constituents were dissolved in an artificial sea water (Kaiyo no Jiten, I960, p. 305, Table I) at various dilutions. For the third series of experiments, $\mathrm{I} \cdot 0 \%$ Polypepton, $0.3 \%$ Lab-Lemco (Oxoid), $0.3 \%$ yeast extract (Difco) and $\mathrm{I} \cdot 2 \%$ agar were dissolved into a complex salt solution (solution $\mathrm{C}$, Table $\mathrm{I}$ ) of various dilution. After counting the colonies, about 30-40 colonies were transferred from a randomly enclosed area of each plate of different salt concentration into the broth media of the same composition as those used for the counting.

The growth dependency of the isolated strains on salt concentration was examined by streaking on plates of agar medium containing $\mathrm{I} \cdot 0 \%$ Polypepton and various concentrations of sodium chloride. The Polypepton was reported to contain $2 \cdot 2 \%$ sodium, $0.5 \%$ calcium and a trace amount of potassium.

Table I. Composition of basal salt solution

\begin{tabular}{lcrcc} 
& $\overbrace{M}^{\text {Artificial sea-water }}$ & \multicolumn{2}{c}{ Solution C } \\
$\mathrm{NaCl}$ & 0.403 & 23.5 & 0.250 & $\mathrm{~g} . / 1$. \\
$\mathrm{KCl}$ & 0.089 & 6.6 & 0.250 & 14.6 \\
$\mathrm{Na}_{2} \mathrm{SO}_{4} \cdot 10 \mathrm{H}_{2} \mathrm{O}$ & 0.028 & 8.9 & - & - \\
$\mathrm{MgCl}_{2} \cdot 6 \mathrm{H}_{2} \mathrm{O}$ & 0.049 & 10.2 & - & - \\
$\mathrm{MgSO}_{4} \cdot 7 \mathrm{H}_{2} \mathrm{O}$ & - & - & 0.025 & 6.2 \\
$\mathrm{CaCl}_{2} \cdot 2 \mathrm{H}_{2} \mathrm{O}$ & 0.010 & $\mathrm{I} \cdot 5$ & 0.010 & 1.5
\end{tabular}

\section{RESULTS}

Viable counts and the concentration of sodium chloride

Plate counts were made on nutrient agar medium containing different amounts of sodium chloride with skin with underlying muscle from a plaice. The remaining part of the same fish was stored for $24 \mathrm{hr}$ at $24^{\circ}$ and plate counts then made on the stored fish. Plates were incubated at $24^{\circ}$, and colonies counted after 4 days. Results from a representative experiment are illustrated in Fig. I. Repeated experiments with plaice and with sardine (Sardinops melanosticta) gave similar relationships of viable count with increasing salt concentration. In all cases the counts showed two peaks at higher salt concentrations, although the position and relative height of the peaks differed in different experiments. The increasing tendency for the bacterial flora to become more halophilic during storage of fish was confirmed in repeated experiments.

\section{Heterogeneity of the isolated strains to salt concentration}

The growth of the isolates from the experiment illustrated in Fig. I was examined on peptone agar containing $\mathrm{NaCl}(\%, \mathrm{w} / \mathrm{v}): 0,0.2,0.5,1,2,3,5,7,10,15$. Before 
testing the growth in these $\mathrm{NaCl}$ concentrations the strains were grown in nutrient broth containing the concentration of sodium chloride as was in the media used for the initial isolation.

Table 2. Relation between the range of salt concentration in which the isolates could grow and $\mathrm{NaCl}$ concentration of the media used for initial isolation

Isolates from media containing $\mathrm{I} \cdot 0,2.0$ and $3.0 \% \mathrm{NaCl}$ were inoculated on $\mathrm{I} \%$ peptone agar containing different $\mathrm{NaCl}$ concentrations. Growth was determined after 5 days of incubation at $25^{\circ}$.

Concn. of $\mathrm{NaCl}$ in media used for the initial isolation from plaice $(\%)$

\begin{tabular}{|c|c|c|c|c|c|c|}
\hline \multirow{3}{*}{$\begin{array}{c}\text { Range of } \\
\mathrm{NaCl} \\
\text { concn. } \\
(\%)\end{array}$} & $I \cdot O$ & $2 \cdot 0$ & $3 \cdot 0$ & $I \cdot O$ & $2 \cdot 0$ & $3 \cdot 0$ \\
\hline & \multicolumn{3}{|c|}{$\begin{array}{l}\begin{array}{l}\text { Isolates from fresh } \\
\text { plaice }\end{array} \\
\end{array}$} & \multicolumn{3}{|c|}{$\begin{array}{l}\text { Isolates from plaice } \\
\text { stored I day at } 24^{\circ}\end{array}$} \\
\hline & \multicolumn{6}{|c|}{$\begin{array}{l}\text { No. of strains grown in the range of } \mathrm{NaCl} \text { concn. } \\
\text { given in the first column }\end{array}$} \\
\hline $0-10$ & o & 0 & 3 & 0 & 0 & 0 \\
\hline $0-7$ & 1 & o & 4 & 2 & 0 & 0 \\
\hline $0-5$ & 3 & I & 2 & 5 & 1 & 4 \\
\hline $0-3$ & 4 & 3 & 3 & 2 & I & I \\
\hline $0-2$ & 6 & 6 & 0 & 0 & 2 & 0 \\
\hline $0-I$ & 3 & 4 & I & 0 & 0 & 0 \\
\hline $0.2-7$ & 0 & 0 & 0 & I & 1 & 0 \\
\hline $0.2-5$ & 0 & 0 & 0 & I & 0 & 1 \\
\hline $0.2-3$ & 0 & 0 & 0 & I & 0 & 0 \\
\hline $0.2-2$ & 0 & I & 0 & 0 & 0 & 0 \\
\hline $0.2-1$ & 3 & 0 & 0 & 0 & 0 & 0 \\
\hline $0.5-7$ & 0 & 0 & 0 & 0 & 0 & 2 \\
\hline $0.5-5$ & 0 & o & 0 & 1 & 0 & 3 \\
\hline $0.5-3$ & 0 & I & 2 & 7 & 5 & 7 \\
\hline $0.5-2$ & 0 & 0 & 0 & 0 & 2 & 0 \\
\hline $0.5-i$ & I & 0 & 0 & 0 & 0 & 0 \\
\hline $\mathrm{I}-7$ & 0 & 0 & 0 & I & 0 & 0 \\
\hline $1-5$ & 0 & I & 0 & 0 & 1 & 0 \\
\hline$I-3$ & 3 & 2 & 6 & 5 & 10 & 4 \\
\hline $1-2$ & 0 & 0 & 0 & 0 & 5 & 0 \\
\hline 1 & 0 & I & 0 & o & 0 & 0 \\
\hline $2-5$ & 0 & 0 & 1 & 0 & 0 & 0 \\
\hline $2-3$ & 0 & 7 & 2 & 0 & I & 5 \\
\hline 2 & 0 & 0 & I & 0 & 0 & 0 \\
\hline 3 & o & 0 & I & 0 & 0 & 1 \\
\hline No growth & 2 & 2 & I & 2 & 0 & I \\
\hline Total & 26 & 29 & 27 & 28 & 29 & 29 \\
\hline
\end{tabular}

The results (Table 2) showed that the bacterial flora of fish consisted of bacteria with different minimum and maximum $\mathrm{NaCl}$ concentrations for growth and that different bacterial groups were selected according to the concentration of $\mathrm{NaCl}$ of the media. After storage for a day at $24^{\circ}$, the numbers of bacteria which could not grow at $\mathrm{NaCl}$ concentrations of lower than $0.2 \%$ had increased remarkably.

The generic composition of the isolates determined according to the scheme of Shewan, Hobbs \& Hodgkiss (I960) is shown in Table 3. Although the numbers of strains examined were not sufficient to draw decisive conclusions, the results seemed to show heterogeneity among the microfloras obtained from the isolation media of 
different $\mathrm{NaCl}$ concentrations. Gram-positive bacteria tended to decrease in numbers with increasing $\mathrm{NaCl}$ concentration, pseudomonads and vibrios seemed to increase at higher $\mathrm{NaCl}$ concentrations.

Table 3. Generic composition of bacteria isolated with media of different $\mathrm{NaCl}$ concentrations

Concn. of $\mathrm{NaCl}$ in media used for the isolation $(\%)$

\begin{tabular}{|c|c|c|c|c|c|c|c|}
\hline 0 & 1.0 & $2 \cdot 0$ & 3.0 & 0 & 1.0 & 2.0 & 30 \\
\hline \multicolumn{4}{|c|}{$\begin{array}{c}\text { Isolates from fresh } \\
\text { plaice }\end{array}$} & \multicolumn{4}{|c|}{$\begin{array}{l}\text { Isolates from plaice stored } \\
\text { I day at } 24^{\circ}\end{array}$} \\
\hline 1 & 4 & 8 & 4 & 3 & 16 & 23 & $2 \mathrm{I}$ \\
\hline 0 & 0 & 6 & 7 & 7 & 5 & 2 & 5 \\
\hline I 3 & 7 & I & 6 & 13 & 4 & 0 & 0 \\
\hline 7 & 5 & 8 & 5 & 2 & I & 0 & 0 \\
\hline 3 & 6 & 3 & 1 & 3 & 0 & 2 & I \\
\hline 4 & 0 & 1 & I & I & 1 & 2 & I \\
\hline 2 & 0 & 0 & 3 & 0 & 0 & 0 & 0 \\
\hline 0 & I & I & 0 & 0 & 0 & 0 & 0 \\
\hline 0 & 3 & I & 0 & 0 & 1 & 0 & I \\
\hline 30 & 26 & 29 & 27 & 29 & 28 & 29 & 29 \\
\hline
\end{tabular}

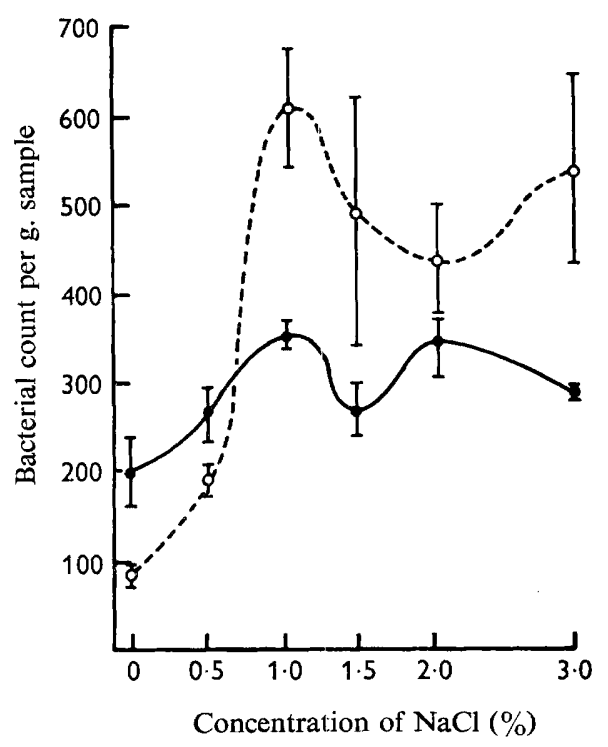

Fig. I

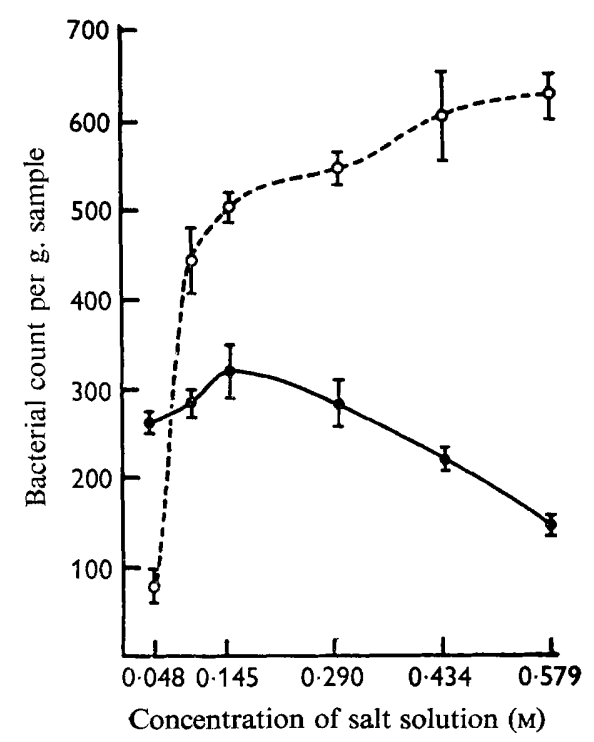

Fig. 2

Fig. I. Relation between viable counts and salt concentration of medium. Results with skin with muscle from: - , fresh plaice (count $\times 10^{-3}$ ); $0---0$, plaice stored $24 \mathrm{~h}$ at $24^{\circ}$, (count $\times 10^{-5}$ ). Vertical lines show standard deviations about means of triplicate plates.

Fig. 2. Relation between viable count and concentration of artificial sea-water in medium. Results with skin + muscle from: $-\infty$, fresh plaice (count $\times 10^{-3}$ ); $0-\ldots .-0$, plaice stored $24 \mathrm{hr}$ at $24^{\circ}$ (count $\left.\times 10^{-6}\right)$, 


\section{Experiments with complex salt solutions}

The use of artificial sea water or other complex salt solutions as a basal solution in the isolation medium was expected to eliminate the inhibitory effect of sodium ion on non-halophilic bacteria and to give different patterns in relation to viable count and salt concentration. Figure 2 shows the results with an artificial sea water, the composition of which is given in Table $I$. The plate counts were made of skin with underlying muscle from a plaice, and colonies counted after the incubation for 4 days at $25^{\circ}$.

During experiments to obtain a medium which would give the highest viable count from a fish sample, a salt solution (solution C, Table I) was developed (Simidu \& Hasuo, 1968). The relation between the viable count of the fish sample and the concentration of this solution was examined. The composition of the basal medium was $(\%, \mathrm{w} / \mathrm{v}): \mathrm{I} \cdot 0$, Polypepton; $0 \cdot 3$, Lab-Lemco; $0 \cdot 3$, yeast extract; $\mathrm{I} \cdot 2$, agar. The constituents were dissolved in solution $\mathrm{C}$ at different dilutions. The media were adjusted to $\mathrm{pH} 7 \cdot 5$.

Table 4. Relation between the range of salt concentration in which the isolates could grow and the concentration of salt solution (solution $C$, Table I) in the media used for the initial isolation

Isolates were inoculated on $\mathrm{I} \%$ peptone agar containing different $\mathrm{NaCl}$ concentrations. Growth was determined after 5 days of inoculation at $25^{\circ}$.

\begin{tabular}{|c|c|c|c|}
\hline \multirow[b]{2}{*}{$\begin{array}{c}\text { Range of } \\
\mathrm{NaCl} \\
\text { Concn. } \\
(\%)\end{array}$} & \multicolumn{3}{|c|}{$\begin{array}{c}\text { Concentration of salt solution } \mathrm{C} \text { in media } \\
\text { used for the initial isolation }(\mathrm{M})\end{array}$} \\
\hline & \multicolumn{3}{|c|}{$\begin{array}{l}\text { No. of strains grown in the range of } \mathrm{NaCl} \\
\text { given in the first column }\end{array}$} \\
\hline $0-10$ & 3 & I & I \\
\hline $0-7$ & 3 & 3 & 4 \\
\hline $0-5$ & 5 & 7 & 10 \\
\hline $0-3$ & IO & 10 & 9 \\
\hline $0-I$ & 6 & 5 & I \\
\hline $0 \cdot 3-7$ & 9 & 2 & 2 \\
\hline $0 \cdot 3-5$ & 2 & 2 & 3 \\
\hline $0 \cdot 3-3$ & 2 & 2 & 0 \\
\hline $0.3-1$ & 2 & I & 0 \\
\hline $1-7$ & 0 & 2 & 6 \\
\hline $\mathrm{I}-5$ & 0 & I & 3 \\
\hline$I-3$ & $o$ & I & 0 \\
\hline 3 & 0 & 0 & I \\
\hline Total & 43 & 37 & 40 \\
\hline
\end{tabular}

Skin with underlying muscle was removed with a sterile knife from the back middle part of plaice weighing $675 \mathrm{~g}$. and cut into three parts. One of these was used immediately for the experiment, and the other two parts were kept in large sterile dishes and stored at $2^{\circ}$ and $24^{\circ}$, respectively, to await further experiments. To protect these samples from drying, a small sterile dish of water was laid beside the cut skin. Skin, $6.0 \mathrm{~cm} .^{2}$ in area, was excised aseptically from each part, and homogenized with a diluent composed of $0.8 \% \mathrm{NaCl}+\mathrm{I} \cdot 0 \% \mathrm{KCl}$. Plate counts were made of serial 


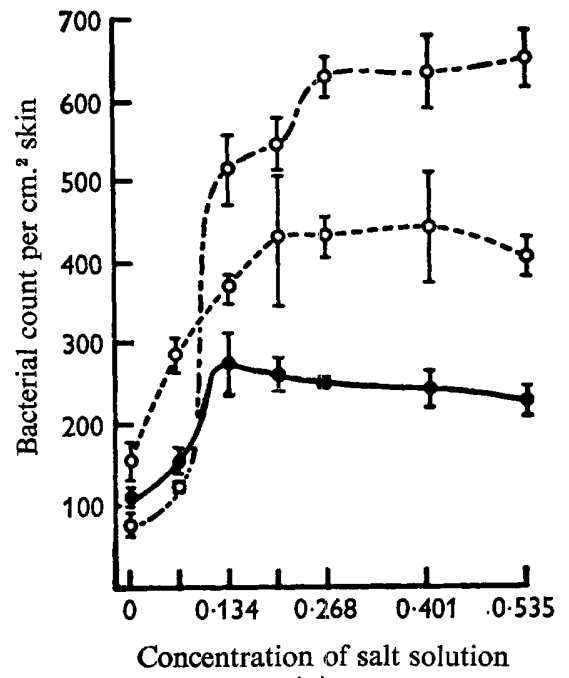

(M)

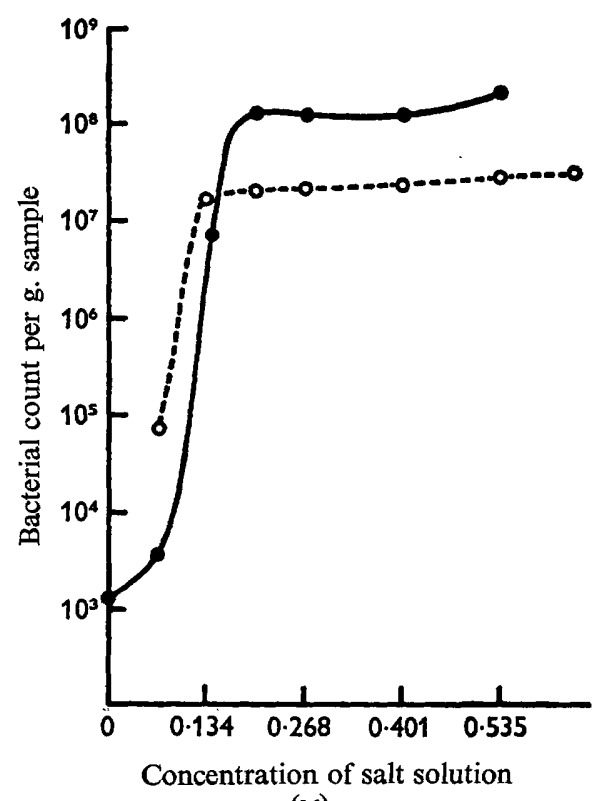

(M)

Fig. 3

Fig. 4

Fig. 3. Relation between viable count and concentration of a complex salt solution (solution $\mathrm{C}$ ) in medium. Results with skin of: - - , fresh plaice (count $\times 10^{-3}$ ); $\mathrm{O}--\mathrm{O}$, plaice stored $24 \mathrm{hr}$ at $24^{\circ}$ (count $\times 10^{-7}$ ); $\bigcirc \ldots .-O$, plaice stored 5 days at $2^{\circ}$ (count $\left.\times 10^{-6}\right)$.

Fig. 4. Relation between viable counts and concentration of a complex salt solution (solution C) in medium.

, Ist experiment, $\mathrm{O} \ldots . . . \mathrm{O}$, 2nd experiment.

Table 5. Generic composition of bacterial flora from the digestive tract of plaice determined by the scheme of Shewan et al. (1960)

\begin{tabular}{|c|c|c|}
\hline \multirow{4}{*}{ acterial genus } & \multicolumn{2}{|c|}{$\begin{array}{l}\text { Concentration of salt solution } \\
\text { (solution } \mathrm{C} \text {, Table I) in media used } \\
\text { for the initial isolation (M) }\end{array}$} \\
\hline & \multirow{2}{*}{\multicolumn{2}{|c|}{ No. of strains }} \\
\hline & & \\
\hline & 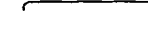 & \\
\hline Vibrio & 38 & 37 \\
\hline Pseudomonas & 2 & 3 \\
\hline Total & 40 & 40 \\
\hline
\end{tabular}

dilutions and the resulting colonies counted after 4 days at $24^{\circ}$. The results obtained are given in Fig. 3.

The range of salt concentration in which the isolated bacteria from fresh fish grew was determined with the peptone agar of different $\mathrm{NaCl}$ concentrations $(\%, w / v)$, $0,0.3,1,3,5,7,10,15$. Care was taken to eliminate the effect of different $\mathrm{NaCl}$ concentrations during precultivation: before streaking on peptone agar, all the strains tested were transferred twice into the medium composed of $1.0 \%$ Polypepton, 
$0.3 \%$ Lab-Lemco, $0.3 \%$ yeast extract and half strength $\mathrm{C}$ solution. A few isolates which failed to grow at this salt concentration were precultured in medium of either full strength or $\frac{1}{5}$ strength of the salt solution. The results after 5 days of incubation at $24^{\circ}$ are summarized in Table 4 . Although there was no appreciable difference among the total numbers of the bacteria initially grown at the three different given concentrations of salts (Fig. 3), the isolated bacteria gave different patterns of growth range according to the salt concentration at the initial isolation.

Along with the experiments with the skin of fish, the relation between growth and salt concentration was examined with the microflora of the digestive tract of the fish. The medium used was the Lab-Lemco + yeast extract agar dissolved in the salt solution $\mathrm{C}$ at different dilutions. Figure 4 shows the results obtained from two experiments, the first with a smaller (216 g.) and the second with a bigger ( $440 \mathrm{~g}$.) fish. The generic composition of the isolates from the second experiment is given in Table 5 .

\section{DISCUSSION}

ZoBell (I94I) studied the salt dependency of the bacterial flora from various sources and showed that maximum viable counts were obtained at the salt concentration corresponding to sea water for the flora of sea water, and at 10-25\% dilution of sea water for the flora of sea mud from terrestrially polluted bays. Our results with an artificial sea water showed that the highest counts were obtained at $25 \%$ dilution of sea water when fresh marine fish were examined. In the experiment with stored fish, the highest counts were obtained at higher salt concentrations A similar relation between salt concentration and viable counts was observed in the experiments with another complex salt solution in which the ionic ratio of sodium to potassium was I: I.

The faster growth of halophilic bacteria at lower as well as higher temperatures is a factor which should be taken into account on the cold storage of fish. Washing fish with tap water or direct contact of fish with ice might eliminate, as is believed by some Japanese workers, the numbers of halophilic bacteria, and might alter the rate and pattern of the spoilage of the fish.

A striking feature observed in the present work was the strong halophilic nature of the bacterial flora from the digestive tract of marine fish. Liston (1957) reported the occurrence of the 'Gut group vibrios' in the gut contents of fish from the North Sea. Whereas the ratio of the vibrios in Liston's experiments was $35-74 \%$ of the total gut flora, the present study showed the gut flora of plaice caught in coastal areas of Japan to be composed almost exclusively of vibrios, and suggests that these vibrios constitute the indigenous microflora of fish intestine.

The authors are grateful to Dr J. M. Shewan (Torry Research Station, Aberdeen) and his staff for reading the manuscript and for helpful suggestions.

\section{REFERENCES}

Liston, J. (I957). The occurrence and distribution of bacterial types on flatfish. J. gen. Microbiol. $16,205$.

Kaiyo no Jiten (Encyclopedia of Oceans) (1960). Ed. by Wadachi, K. Tokyo: Tokyo-do.

Shewan, J. M., Hobrs, G. \& Hodgkiss, W. (1960). A determinative scheme for the identification of certain genera of Gram-negative bacteria, with special reference to the Pseudomonadaceae. J. appl. Bact. 23, 379 . 
SimidU, U. \& AIso, K. (1962). Occurrence and distribution of heterotrophic bacteria in sea-water from the Kamogawa Bay. Bull. Jap. Soc. Scient. Fish. 28, I 133.

Simidu, U. \& HASUO, K. (I968). An improved medium for the isolation of bacteria from marine fish. J. gen. Microbiol. 52, 355.

Yanagita, T. \& MaruYama, Y. (I953). Mechanical pipette for microbiological studies. A. Rep. Inst. Food Microbiol., Chiba Univ. 6, 80.

ZoBell, C. E. (194I). Studies on marine bacteria. I. The cultural requirements of heterotrophic aerobes. J. mar. Res. 4, 42. 